Pamiętnik Literacki 2015, 3, s. 105-123
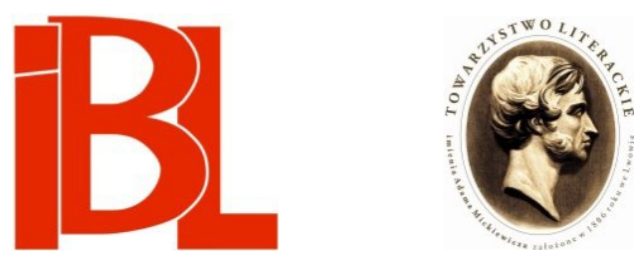

\title{
Doświadczenie i pamięć z otwartą furką. Maxim Biller o Brunonie Schulzu
}

\author{
Agnieszka Hudzik
}


AGNIESZKA HUDZIK Freie Universität Berlin

\section{DOŚWIADCZENIE I PAMIĘĆ $Z$ OTWARTĄ FURTKĄ MAXIM BILLER O BRU- NONIE SCHULZU}

\section{Maxim Biller i tajemnicza przesyłka z Drohobycza}

W listopadzie 2013 prasa niemiecka wielokrotnie rozpisywała się o życiu i twórczości Brunona Schulza, jego autoportret lub rysunek znaleźć można było w gazetach na pierwszych stronach działów $\mathrm{z}$ felietonami. Okazję ku temu dała jednak nie rocznica tragicznej śmierci artysty, ale ukazanie się nowej książki jemu poświęconej - choć może ta zbieżność obydwu wydarzeń nie jest całkiem przypadkowa; wygląda to raczej na zamierzony zabieg marketingowy. Chodzi o niespełna 70-stronicową nowelę Maxima Billera Im Kopf von Bruno Schulz, opublikowaną przez wydawnictwo Kiepenheuer \& Witsch ${ }^{1}$. Choć nie jest to dzieło pokaźne objętościowo, wywołało ono liczne pozytywne reakcje recenzentów: np. Ijoma Mangold (,Zeit”) widzi w nim wielki kadysz, w którym Biller poprzez tragigroteskę próbuje zmierzyć się z losem pisarza z Drohobycza, a Michael Krüger („Frankfurter Allgemeine Zeitung") mówi o intrygującym hołdzie pamięci Schulza, pełnym aluzji do jego opowiadań, zachęcającym do ich wnikliwego czytania ${ }^{2}$.

Kto zwykle sceptycznie podchodzi do takiego typu ogólnikowych artykułów i na bieżąca krytyke literacka - $\mathrm{z}$ jej rozemocjonowaniem i szybkimi osądami - patrzy raczej z przymrużeniem oka, ten mógłby i w tym wypadku mieć pewne wątpliwości. Trudno bowiem uwierzyć w tak powszechny aplauz... Czy to zasługa - myśli czytelnik - jakichś szczególnych nakładów wydawnictwa na reklamę i promocję książki? Była ona od dłuższego czasu głośno anonsowana, a jej oficjalna premiera odbyła się w Deutsches Theater w Berlinie. Czy za pochwałami krytyków stoi niekwestionowana pozycja autora, uważanego w Niemczech za specjalistę w sprawach literatury żydowskiej, którego trudno krytykować i z którym niezręcznie wchodzić

$1 \quad$ M. Biller, Im Kopf von Bruno Schulz. Köln 2013. Niniejszy artykuł powstał w listopadzie 2013, a w 2014 roku ukazał się polski przekład omawianej noweli: M. Bille r, W głowie Brunona Schulza. Przeł. M. Miroń s ka. Warszawa 2014.

2 I. Mangold, Grotesk wie der Tod. „Die Zeit” 2013, nr 46, z 16 XI. Na stronie: www.zeit.de/2013/46/ maxim-biller-im-kopf-von-bruno-schulz (data dostępu: 28 VII 2015). - M. Kr ü g e r, In jeder Ecke ein dicker Klumpen Angst. „Frankfurter Allgemeine Zeitung” 2013, nr z 8 XI. Na stronie: www.faz. net/aktuell/feuilleton/buecher/rezensionen/belletristik/maxim-biller-im-kopf-von-bruno-schulzin-jeder-ecke-ein-dicker-klumpen-angst-12651360.html (data dostępu: 28 VII 2015). 
w polemike?? Czy wreszcie jest to wynik zwykłej zmowy znajomych z „branży”, przychylnej należącemu do niej aktywnemu publicyście i felietoniście Billerowi?

Nie sposób od razu potraktować tych pytań jako bezzasadne. Wymienione w nich mechanizmy rynkowe są przecież dobrze znane w dzisiejszym świecie literackim. Można więc mieć wiele uprzedzeń, sięgając po tę lekturę. Ale jest też przy tym prawdą, że nazwisko autora ma na niemieckim rynku literackim swoją dobrze rozpoznawalną markę w kwestiach związanych $\mathrm{z}$ szeroko pojętą tematyką żydowską. Biller - urodzony w 1960 roku w Pradze w rodzinie o rosyjsko-żydowskich korzeniach, przeprowadził się jako dziecko do Niemiec Zachodnich - w swojej twórczości od samego początku konsekwentnie skupia się na problemach dotyczących bycia Żydem we współczesnym świecie. Jego debiutancką powieść Wenn ich einmal reich und tot bin (1990, Jak już będę kiedyś bogaty i martwy) określano nawet jako zapowiedź powrotu niemieckojęzycznej literatury żydowskiej. Pisarz chętnie sięga bowiem po motywy związane $z$ tradycja judaistyczną. Poza tym postaci $z$ jego dzieł często borykają się $\mathrm{z}$ wyzwaniem/piętnem swojego pochodzenia, jak np. architekt Luria w zbiorze opowiadan Land der Väter und Verräter (1994, Kraj ojców i zdrajców) albo Motti Wind z Izraela w powieści Die Tochter (2000, Córka) czy też ostatnio sam autor, który w ironicznej autobiografii Der gebrauchte Jude (2009, Zużyty Żyd) szuka odpowiedzi na pytanie o to, kim jest. W tym kontekście nie można również pominąć informacji, że Biller publikuje w gazetach swoje teksty, m.in. prowadzi we „Frankfurter Allgemeine Zeitung” stałą rubrykę satyryczną, której bohaterem jest pisarz Żyd, pechowiec i życiowy nieudacznik.

Żeby jednak oddać sprawiedliwość Billerowi, trzeba też przyznać, iż cieszy się on powszechna rozpoznawalnością nie tylko dzięki swojej twórczości. Medialnego rozgłosu przysporzyła mu kilka lat temu atmosfera skandalu, w jakiej ukazała się jego wcześniejsza powieść Esra. Była partnerka pisarza i jej matka dopatrzyły się w przedstawionych tam postaciach podobieństw do siebie, dlatego wniosły sprawę do sądu. Proces miał charakter precedensowy, toczył się przez kilka lat; $z$ petycja w obronie Billera występowali m.in. Günter Grass i Elfriede Jelinek, w końcu Federalny Trybunał Sprawiedliwości umorzył postępowanie, powołując się na wolność sztuki - wydawnictwo uniknęło horrendalnego odszkodowania, powieść jednak została prawnie wycofana ze sprzedaży. Koniec końców książka jest nadal dostępna w bibliotekach, a ostatnio w Izraelu ukazał się jej hebrajski przekład. Poza tym Biller ma od jesieni występować we wznowionym po latach legendarnym programie telewizyjnym o nowościach wydawniczych „Das Literarische Quartett”, emitowanym na kanale publicznym ZDF, prowadzonym niegdyś przez „papieża niemieckiej literatury”, Marcela Reicha-Ranickiego. Można domniemywać, iż udział w tym przedsięwzięciu zaproponowano Billerowi ze względu na to, że jest on znany również ze swoich kontrowersyjnych tez i z prowokowania burzliwych debat w prasie. Ostatnio, w 2014 roku, na łamach gazety „Die Zeit” opublikował artykuł, w którym narzeka na stan współczesnej literatury niemieckiej, i twierdzi, iż jedyny ratunek przed nuda i autotematyzmem stanowią książki „imigrantów”. Do grona tych ostatnich zalicza m.in. laureatów Nagrody im. Adelberta von Chamissa, przyznawanej osobom tworzącym w języku niemieckim i mającym pochodzenie imigranckie - stąd też na określenie ich dzieł używa się często neologizmu „Chamisso-Literatur”. Ale i wobec nich Biller nie pozostaje całkowicie bezkrytyczny, dostrzega bowiem pewien me- 
chanizm degradacji, jakiemu oni ulegają, pisząc zwykle na początku swojej kariery rzeczy artystycznie udane, dotykające trudnych tematów, własnych doświadczeń i egzystencji między kulturami, w kolejnych zaś utworach obniżając loty za sprawą nacisków ze strony branży wydawniczej. W ten sposób adaptują się do warunków panującej na rynku nijakości artystycznej. Jako przykład takiej właśnie mimikry Biller podaje książki Sašy Stanišicia i pokazuje rozdźwięk między jego powieściami: pierwszą, doskonałą, o wojnie bałkańskiej, Jak żołnierz gramofon reperował, i drugą, zdaniem Billera, artystyczną klapa - Noc przed festynem, której akcja toczy się w prowincjonalnym miasteczku wschodniej części Niemiec ${ }^{3}$. Po tym artykule przez prasę niemiecką przetoczyła się burza krytyki, zarzucającej Billerowi, że etykietuje, dzieli pisarzy na „imigrantów” i „prawdziwych Niemców”, sugeruje, jakoby kwestia pochodzenia miała wpływ na wartość literacką utworów, oraz insynuuje, że rynek wydawców jest zdominowany przez pokolenie postnazistowskich biznesmenów.

Wspomniane tu obawy, iż książka Im Kopf von Bruno Schulz, w tak zakreślonym „polu produkcji literackiej” (termin Pierre’a Bourdieu), nie może być niczym więcej jak tylko pusta „wydmuszka”, okazują się płonne. Przemawia za tym wiele elementów, o których będe jeszcze pisała. Już sam tytuł noweli intryguje i przyciaga, trudno przejść obok niego obojętnie: jakie to mianowicie myśli mają kłębić się w głowie Schulza?

Pytanie to zdaje się od dawna frapować zarówno jego akademickich badaczy, jak i artystycznych, duchowych potomków. Nie trzeba daleko szukać możliwych na nie odpowiedzi - wystarczy wybrać się do Drohobycza. W gimnazjum, w którym Schulz nauczał, znajduje się mała sala - muzeum poświęcone pisarzowi. Tam, prawie pośrodku, na wysokim cokole stoi rzeźba przedstawiająca Schulza. Z przodu klasyczne popiersie: wyraźne rysy, wzorowane na autoportretach; twarz trójkątna, koścista, wzrok nieśmiało spuszczony w dół; głowa podparta na lewej dłoni, a druga ręka jakoś dziwnie leży pod broda, jakby nienaturalnie krzywa, podkulona, odgradzająca się od świata zewnętrznego - zalotnie dystansujący się gest, jak na znanym zdjęciu Schulza z notatnikiem na schodach domu przy ulicy Floriańskiej. Rzeźba oglądana $z$ tyłu prezentuje zaś wnętrze głowy pisarza, przekrój poprzeczny przez jego myśli. Tam rozgrywa się jedna ze scen z Xięgi Bałwochwalczej- Odwieczna baśń (I). Naga kobieta, leżąca na podniebnej sofie, kładzie od niechcenia stopę na twarzy mężczyzny, korzącego się gdzieś na dole, a przy jej drugiej stopie, spoczywającej wygodnie na poduszkach, siedzi skrzydlaty stwór, który obserwuje całe wydarzenie. Być może, ten właśnie rzeźbiarski wizerunek był jedną z inspiracji dla Billera. Przywołałam to dzieło, ponieważ bardzo wymownie (i trójwymiarowo) obrazuje ono nieukojone pragnienie, widoczne u wymienionych dwóch grup odbiorców twórczości Schulza: uwodzącą chęć czy wręcz potrzebę „zajrzenia mu do głowy”, zbliżenia się doń i wniknięcia w jego wyobraźnię, podjęcia z nią dialogu. Tym kie-

M. B ill e r, Letzte Ausfahrt Uckermark. Warum ist die Gegenwartsliteratur so langweilig? „Die Zeit” 2014, nr 9, z 20 II. Artykuł na stronie: http://www.zeit.de/2014/09/deutsche-gegenwartsliteratur-maxim-biller (data dostępu: 28 VII 2015). Książki S. Stanišicia ukazały się też w Polsce w przekładzie A. Ro s e na u (Wołowiec 2008; Warszawa 2015). 
ruje się także Biller w swojej noweli i niejako powtarza literacko gest ujęty w rzeźbie przedstawiającej popiersie Schulza.

Gest ów, oczywiście, nie jest wyjątkowy. Autor książki nie wchodzi na ziemię niczyją. Recepcja dzieła Schulza to temat sam dla siebie, niejednokrotnie starano się ją opisać i uporządkować: dzielono ją na okresy historyczne, analizowano w poszczególnych krajach i kręgach kulturowych ${ }^{4}$. Gdyby w owym bogatym i różnorodnym materiale zechcieć wyróżnić recepcję naukową, krytycznoliteracką i szeroko rozumianą artystyczną, to tę ostatnią kategorię chyba najtrudniej byłoby opanować systemowo. Nawet jeśliby się pominęło inne dziedziny sztuki, ograniczyło się zaledwie do literatury - co niewątpliwie byłoby z uszczerbkiem dla całej spuścizny Schulza - i w niej spróbowało prześledzić wpływy, zapośredniczenia i intertekstualne nawiązania do jego prozy, uwzględniając przy tym jeszcze perspektywę międzynarodową (dzieła Schulza przetłumaczone są obecnie na ponad 20 języków) oraz historyczną (od opublikowania pierwszych opowiadań aż po współczesność), to ogrom pola badawczego byłby po prostu niewyobrażalny. Spośród wielu utworów, w których pojawiają się Schulzowskie motywy i tropy, dałoby się jednak wyodrębnić pewna, już nieco mniej liczną, podgrupę - mianowicie fikcje literackie z Schulzem, jego osobą i/lub manuskryptami w roli głównej. Takich książek jest też niemało, ich omówienie, przeanalizowanie, a także porównanie stanowi właściwie materiał na osobną monografię. Do najbardziej znanych dzieł należą m.in. Un uomo che forse si chiamava Schulz (Człowiek, który być może nazywał się Schulz) włoskiego pisarza Uga Riccarellego czy też powieść Patrz pod: Miłość Davida Grosmana, w której w jednym $z$ rozdziałów Schulz nie zostaje zabity, lecz udaje się nad morze i - przemieniony symbolicznie w rybę - przyłącza się do ławicy łososi. Warto także wspomnieć o intrydze kryminalnej Cynthii Ozick Mesjasz ze Sztokholmu oraz o powieści epistolarnej serbskiego autora Mirka Demicia Ćilibar, med, osorusa (Bursztyn, miód, jarzębina), składającej się z korespondencji miłosnej Schulza do tajemniczej kochanki, nauczycielki ${ }^{5}$. Otóż w ten właśnie nurt literacki wpisuje się

4 Istnieje kilka monograficznych opracowań prozy Schulza w języku niemieckim. Są to zwykle rozprawy doktorskie o różnej wartości. Pierwsze pojawiły się jeszcze w latach siedemdziesiątych: E. G ośli c ki - B a u r, Die Prosa von Bruno Schulz. Bern 1975. - K. D u la i m i, Der Mythosbegriff im Werk von Bruno Schulz. München 1976 (rozprawa napisana pod kierunkiem znanego polonisty, H. Kunstmanna). - L. Ste in h off, Rückkehr zur Kindheit als groteskes Denkspiel. Hildesheim 1984. W ostatnim czasie ukazały się dwie prace: J. A u g s b u r g er Masochismen: Mythologisierung als Krisen-Ästhetik bei Bruno Schulz (Hannover 2008; fragmenty tej książki opublikowano w języku polskim: Masochizmy. Mitologizacjajako estetyka kryzysu w twórczości Brunona Schulza. Przeł. K. Lu ka s. „Przestrzenie Teorii” 2011, nr 15) oraz B. A. B i e n i e k Bruno Schulz' Mythopoesie der Geschlechteridentitäten: der Götzenblick im Gender-Spiegel (München 2011; recenzja tej książki: M. P. Mark ow ski, Book review. „Slavic Review” t. $72\langle 2013\rangle$, nr 1). Bibliografię tę uzupełniaja liczne artykuły, m.in. autorstwa slawistek R. La c h ma n n (Demiurg i jego fantazmaty. Spekulacje wokót mitologii stworzenia $w$ dziele Bruna Schulza. Przeł. J. Balbierz. Przekład przejrzał P. La c h ma n n. „Teksty Drugie” 1999, nr 6) i B. Helbi g - M i s c h ew ski (Między omnipotencja a niemoca, gloryfikacja a denuncjacja. O rozpadzie „porzadku Ojca” i masochizmie $w$ twórczości Brunona Schulza. Przeł. G. Mat u s ze k. „Przestrzenie Teorii” 2007, nr 8). Schulz pojawia się także często w kontekstach komparatystycznych, np.: J. S c h u l te, Eine Poetik der Offenbarung: Isaak Babel', Bruno Schulz, Danilo Kiš. Wiesbaden 2004.

5 U. Ric a relli, Un uomo che forse si chiamava Schulz. Casale Monferrato 1998. - D. G ro s m a n, Patrz pod: Miłość. Przeł. M. S o mmer. Warszawa 2008. - C. Ozick, Mesjasz ze Sztokhol- 
omawiany utwór. Billera fascynuje wątek zaginionego manuskryptu. Punktem wyjścia akcji jest list Schulza do Thomasa Manna, wysłany jakoby przed wybuchem drugiej wojny światowej wraz z jedynym stworzonym po niemiecku opowiadaniem Schulza Die Heimkehr (Powrót do domu). Jak autor radzi sobie $\mathrm{z}$ tą fikcyjna fabułą? Do czego jest mu ona potrzebna? Czy to tylko kolejna wersja detektywistycznej historii, podgrzewającej nadzieje na istnienie jeszcze jednego, zaginionego, autentycznego dzieła?

Wydaje się, że taka książka musiała w końcu powstać - i to nie gdzie indziej, jak tylko w Niemczech. Schulzowska proza obecnie przeżywa swoją drugą wiosnę na tamtejszym rynku czytelniczym, a to za sprawa publikacji nowego znakomitego przekładu opowiadań, które przygotowała austriacka tłumaczka Doreen Daume: w roku 2008 ukazał się tom Die Zimtläden (Sklepy cynamonowe), w 2011 Das Sanatorium zur Sanduhr (Sanatorium pod Klepsydra). Nowela Billera to zatem jakby echo tego wydania, a kto wie, może nawet coś znacznie więcej: początek wielkiej fali nowej recepcji twórczości Schulza. Rzecz jednak nie w modzie na autora Sklepów cynamonowych - bardziej chyba w samym temacie: w owym adresowanym do niemieckiego noblisty, nadanym $z$ Drohobycza zaginionym liście... Wśród badaczy jest on owiany legendą. Wielokrotnie analizowali i potwierdzali oni intertekstualne odniesienia Schulzowskiej prozy do dzieł Manna, darzonych przez polskiego pisarza wielką atencją, zwłaszcza do cyklu powieściowego o biblijnym Józefie. Niektóre interpretacje idą jeszcze o krok dalej i poszukują obustronnych zależności między dwoma autorami - dostrzegają nie tyle Schulza zachwyconego Mannem, ile Manna zainspirowanego Schulzem. Wskazują przy tym na uderzające podobieństwo postaci ojca Adriana Leverkühna z powieści Doktor Faustus do Jakuba z Schulzowskich opowiadań i snują domysły, iż Mann mógł przeczytać wspomniany manuskrypt Heimkehr, w którym pojawiały się, być może, motywy i bohaterowie znani z wcześniejszych publikowanych dzieł Schulza. Fantazje i domysły zdają się snuć samoczynnie, i to szczególnie po aferze w Thomas-Mann-Archiv w Zurychu, które zyskało w jej wyniku opinię wyjątkowo bałaganiarskiej instytucji. W czerwcu 2013 wyszło mianowicie na jaw, że znaleziono tam przypadkiem - bagatela - kilkanaście nie otwieranych do tej pory skrzyń po żonie pisarza, Katii Mann, zawierających ponad 3000 zapomnianych listów (m.in. od Hermanna Hessego, Liona Feuchtwangera czy Brunona Waltera). Taki stan rzeczy aż prosi się o literacką in(ter)wencję.

\section{Treść}

Biller bierze zatem na swój warsztat literacki temat legendarnego listu do Manna i rozpracowuje ów motyw w sposób iście intrygujący. Tworzy klasyczną nowelę, w której akcja zawiąuje się stopniowo. Rozpoczyna się raczej banalnie: Schulz zastanawia się, jak odpowiednio utytułować noblistę w nagłówku listu. Zaraz potem następuje realistyczne osadzenie w czasie: jest listopad 1938. W tekście przeplatają się ze sobą, dość konwencjonalnie, dwie linie narracyjne: piszącego list Schul-

mu. Przeł. Joteł [właśc. J. Łoziński]. Poznań 1994. - M. Demić, Ćilibar, med, osorusa. Beograd 2001. Fragmenty polskiego tłumaczenia A. Ła s ek opublikowane w „Poboczach” (2006, nr 4). 
za-narratora komentuje i uzupełnia trzecioosobowy zewnętrzny narrator. Dzięki tej zmianie perspektyw zarysowuje się w miarę dokładny obraz autora Sklepów cynamonowych. W fabułę całkiem zgrabnie wkomponowane zostają najważniejsze fakty $z$ jego życia: nauczyciel w gimnazjum, biegła znajomość języka niemieckiego, studia we Lwowie i jakiś czas w Wiedniu; dowiadujemy się o atmosferze domu rodzinnego, o dzieciństwie, śmierci ojca i matki, o spoczywającym na Schulzu obowiązku utrzymania siostry z dziećmi, o byłej narzeczonej - tłumaczce Procesu Franza Kafki, o zerwanych zaręczynach, o nagrodzie Polskiej Akademii Literatury, o planach pisania powieści Mesjasz. Poza tym bezpośrednio wspomniane sa tytuły innych utworów, takich jak np. Traktat o manekinach ${ }^{6}$. Tekst powtarza również znane wątki składające się na mit Schulza-artysty. Mowa jest o jego ambiwalentnym stosunku do judaizmu - o tym, że bliższe niż religia jest mu życie bohaterów wielkiej literatury, Malte-Lauridsa Briggego czy Gustawa von Aschenbacha; o idealizacji dzieciństwa i życzeniu, by ono nigdy nie przeminęło. Do tego dochodzi też element sadomasochistyczny, nie tylko w odniesieniu do erotyki - artysta jako podmiot wydaje się $z$ jednej strony słaby, uległy, $z$ drugiej zaś narcystyczny, żądny perwersji. Wizerunku dopełnia Hassliebe do rodzinnego miasta, które Schulz kocha i jednocześnie nienawidzi go, marzy o światowych stolicach, chce raz na zawsze opuścić Drohobycz, ale nie potrafi $z$ nim się rozstać.

Billerowi nie zależy jednak najbardziej na wierności portretu biograficznego. Autor dąży raczej do czegoś zgoła innego - stopniuje intrygę, powoli odrywa czytelnika od konwencjonalnych sposobów postrzegania świata po to, by wciągnąc go w swoją wykrzywiona, dziwaczną rzeczywistość. Taką strategię narracyjna pisarz zdradza zresztą wprost w motcie do swego dzieła, którym są słowa Szmuela Josefa Agnona: „Pochwalony niech będzie ten, kto powołuje do życia dziwne twory”.

6 Co ciekawe, w tytule traktatu pada wyraz „Schneiderpuppen”, pochodzacy z nowego tłumaczenia autorstwa D. Da u me. We wcześniejszym przekładzie J. Hah na (München 1961) pojawiało się w tym miejscu słowo „Mannequins”, które obecnie, nieco staromodne, zmieniło swoje znaczenie, bo kojarzą się z nim głównie manekiny z witryn sklepowych - postaci z plastiku, mające wszystkie części ciała. Daume zdecydowała się posłużyć tu wspomnianym słowem „Schneiderpuppe” (literalnie: krawiecka lalka), oddającym dokładniej sens polskiego rzeczownika „manekin”, który Schulz mógł mieć na myśli: "niepełna figura z drewna i materiału, używana w krawiectwie, bez głowy i kończyn, na wysokim stojaku'. Takie właśnie manekiny symbolizowały niedoskonałą demiurgię, „wtórą Księgę Rodzaju”. Tłumaczenie tego wyrazu jest chyba najistotniejszą, niemal sztandarową, zmianą, jaką wniósł nowy przekład, co starano się także zaznaczyć na okładce tego wydania, na której widnieją kukły krawieckie: bezrękie torsy na stojakach z drewnianymi kulkami zamiast głów. Zob. D. D a u m e, Nachwort. „Eine Brücke ins Ausland”. W: B. S c h u lz, Die Zimtläden. Neu übers. D. D a u me. München 2008, s. 215-221.

7 Cyt. za: Biller, W głowie Brunona Schulza, s. 5. Szmuel Josef Agnon (właśc. Szmuel Josef Czaczkes, 1888-1970), pisarz z pokolenia Schulza, urodzony w galicyjskim Buczaczu, otrzymał w 1966 roku razem z N. Sachs literacką Nagrodę Nobla jako pierwszy autor piszacy w języku hebrajskim. Choć rodzinne strony opuścił dosyć wcześnie - w 1908 roku wyemigrował do Palestyny, potem do Niemiec, by następnie powrócić do Jerozolimy - to wywarły one jednak silny wpływ na jego twórczość. Szczególnie klimat żydowskich sztetli i opowieści chasydzkie. Zaprzyjaźniony był z M. Buberem. Cytowane przez Billera zdanie pochodzi z jednego z pierwszych dzieł Agnona, jakim było opowiadanie napisane w Jafie, tuż po przeprowadzce do Palestyny, opublikowane w 1912 roku pt. We-haja he-akow le-miszor (רושימל בוקעה היהו). Do tej pory nie było ono drukowane w Polsce, po niemiecku, w tłumaczeniu M. Stra ußa, ukazało się w Berlinie już w 1918 roku, przekład an- 
W noweli mamy zatem dwa nurty akcji, które powoli nachodzą na siebie - o tym jednak potem. Billerowski Schulz opowiada w liście do Manna historię, która z minuty na minutę staje się coraz bardziej niebywała. Całkiem podobnie jak niegdyś robił to ponoć sam drohobycki pisarz w trakcie swoich lekcji, kiedy - według wspomnień jego uczniów - fantastycznymi baśniami starał się przyciągnąć ich uwagę i zainteresowanie. W tym przypadku zastosowany jest taki sam chwyt: literacki Schulz chce swoimi słowami zaintrygować adresata listu i poprosić go przy okazji o pomoc w publikacji swoich opowiadań za granica. Zdaje jakoby rzeczową relację ze zdumiewających wydarzeń, która jednakowoż niepostrzeżenie przechodzi w „bajanie”. Ale jest to bajanie, rzec by można, „na serio”, a więc nie jakieś nieszkodliwe fantazjowanie, lecz sprawa znacznie poważniejsza, za którą czai się das Unheimliche - coś groźnego, apokaliptycznego, niepokojąco-niesamowitego. Granice między wyobrażalnym a niewyobrażalnym, między możliwym, prawdziwym lub prawdopodobnym a zupełnie nierealnym stają się tu płynne, zacierają się. Zamysł artystyczny utworu Billera polega na unaocznieniu i zdemaskowaniu na wielu poziomach całej tej narracyjnej magii.

Ale po kolei. Intryga jest następująca: Schulz chce poinformować Manna, że do Drohobycza przyjechał człowiek, który się za niego podaje. Ponieważ wszyscy w mieście znają autora Czarodziejskiej góry jedynie z fotografii prasowych, biora przybysza za „oryginał”, choć nadawca listu od samego początku uważa go za po-

gielski jest zaś aktualnie w przygotowaniu (pt. And the Crooked Shall be Made Straight w wydawnictwie Toby Press). Tytuł nawiązuje do biblijnego wersetu z Księgi Izajasza (40, 4): „i będą krzywe prostymi, a ostre drogami gładkimi” (cyt. z: Pismo święte Starego i Nowego Testamentu. Przeł. J. W u j e k. Tekst poprawili i krótkim komentarzem opatrzyli S. Sty ś, W. Lo h n. Kraków 1962, s. 725). W niemieckim przekładzie nie udało mi się odnaleźć w pełnym brzmieniu zdania cytowanego przez Billera. Wydaje się jednak, że prześledzenie intertekstualnych relacji między opowiadaniem $W$ głowie Brunona Schulza a dziełem Agnona to temat na osobne studium. Agnon pisze w stylu przypowieści biblijnej, narrator często wplata w historię anafory sławiące Boga, wielekroć powtarzany jest zwrot "pochwalony niech będzie”. Bohaterem opowiadania - składającego się z 4 części i epilogu - jest Menascheh Chajim, który wraz z żoną prowadził w Buczaczu sklep. Nie mieli potomstwa, byli biedni; gdy stracili wszystko, żona wysłała go na żebry. Dla powodzenia tej wyprawy Chajim dostał od rabina list polecający, z którym wędrował po okolicach. Gdy już uzbierał pieniądze i chciał wracać do domu, trafił na oszusta, który namówił go, żeby odsprzedał mu ów list. Chajim ze szczęścia przepił zapłatę, a po dłuższym czasie zjawił się w rodzinnym miasteczku, gdzie nikt go już nie rozpoznał. Oszust umarł, a jako że miał przy sobie pismo rabina, ludzie wzięli go za Chajima i uznali go za martwego, jego żona zaś ponownie wyszła za mąż i urodziła dziecko. Bohater postanowił się nie ujawniać, zawrócił, nie chcąc burzyć szczęścia innych, błąkał się po cmentarzach. Pomysł fabularny na upozorowanie własnej śmierci nie jest szczególnie oryginalny, przeciwnie: to motyw dobrze znany w literaturze powszechnej, stosowany przez takich autorów, jak chociażby L. Tołstoj w Żywym trupie, R. Musil w opowiadaniu Kos czy L. Pirandello w powieści Świętej pamięci Mattia Pascal. Często towarzyszy mu klasyczny topos „nostos”, powrotu do domu bohatera, który - jak Odyseusz - po wieloletniej nieobecności uchodzi wśród najbliższych za zmarłego. Jednak to nie ten motyw zdaje się intrygować Billera. Wykorzystuje on podobne figury narracyjne co Agnon, zwłaszcza te, które w epilogu opowiadania służą do przedstawienia postawy głównego bohatera wobec traumatycznych doświadczeń. Chajim, widząc swoją bliską śmierć, płacze i śmieje się równocześnie (S. J. Ag n o n, Und das Krumme wird gerade. Übers. M. St r a u 3. Berlin 1918, s. 148), mimo tylu nieszczęść nie porzuca wiary i akceptuje swój los. Recytując psalmy, w których pobrzmiewa nadzieja, z cichym uśmiechem na twarzy zastanawia się także, co by było, gdyby cała ta historia w ogóle się nie wydarzyła (s. 152) - to temat przewodni noweli Billera. 
dejrzanego. Sytuacja staje się coraz bardziej groteskowa, pojawia się w niej czarny humor i nastrój oniryczny, jak ze snu na jawie albo... z opowiadań Schulza. Biller nie tylko stara się oddać atmosferę Schulzowskiej prozy, ale i wirtuozersko bawi się jej motywami, wręcz żongluje nimi. Rozszyfrowywanie ukrytych aluzji i intertekstualnych odniesien to niewątpliwie jedna $z$ największych przyjemności omawianej lektury. Przedstawię tu niektóre $z$ nich.

Przede wszystkim rozpoznawalny jest klimat opisywanych pomieszczeń, nie do końca dających się określić, półmrocznych i dusznych. Schulz pisze list i pracuje w suterenie pod kuchnia, przez niewielkie okno pod sufitem widzi skrawek ulicy - postrzega świat niejako „od dołu”, z perspektywy leżącego na ziemi, i do tego niewyraźnie, przez brudne szyby. Ponadto w pokoju panuje nadmiar przedmiotów, wszędzie leżą porozrzucane papiery, naokoło wiszą rysunki. Meble sa za niskie, Schulz permanentnie musi się pochylać, kreśli list, zwijając się na podłodze. Przestrzeń jest nieprzewidywalna, labilna, niewymierna, jakby żywa. Bohatera prześladuje wrażenie, że ze ścian wypełzną węże lub jaszczurki ${ }^{8}$. Także przedmioty są w tej noweli obdarzone życiem: uderzona kanapa może przebiec do innego pokoju. Trudno ustalić ich położenie i wymiary - podczas odczytu Manna-sobowtóra w aptece słuchacze rozsiadają się wygodnie w... szufladach, niczym subiekci na półkach $\mathrm{z}$ belami materiałów w ojcowskim sklepie w opowiadaniach Schulza. Poczucie niemożności dookreślenia otoczenia bohatera idzie w parze $\mathrm{z}$ pulsującym w tekście „podskórnym” doświadczaniem czegoś nieogarniętego i niesamowitego - w atmosferze swojskich, codziennych zajęć wciąż narasta napięcie, oczekiwanie na niezwykłe wydarzenie. Nie ma w tym jednak patosu retorycznego ani grozy romantycznej. To raczej złowrogie napieranie nieuniknionej katastrofy.

Jawnymi nawiązaniami do twórczości Schulza są też z pewnością motywy zwierząt. Oprócz tego, że w tekście stale pojawiają się animalistyczne porównania czy metafory (ołówek toczy się po podłodze jak mysz, itp.), występują tam także, przede wszystkim, bliżej nieokreślone postaci pół zwierząt, pół ludzi. Uczniowie ukazani sa jako ptaki, mają skrzydła, dzioby, latają nad dachem ratusza. Wątek ptaków, a raczej ich plagi, ptasich piór i ekskrementów, stale zreszta powraca

$8 \quad$ Na marginesie uwaga natury translatorskiej: niemieccy tłumacze Schulza musieli się zmierzyć ze stosowanymi przez niego frazami, których zadanie polega na ożywianiu przestrzeni, co stanowi jeden $z$ istotnych elementów/reguł jego poetyki. Są to przykładowo takie zdania, jak: „Każda szczelina mogła wystrzelić z nagła karakonem” (B. Schulz, Karakony. W: Opowiadania. - Wybór esejów i listów. Oprac. J. J a rzę b s ki. Wyd. 2, przejrz. i uzup. Wrocław 1998, s. 88. BN I 264). O. Kühl (Was macht die Zunge mit uns? „Magazin Polenplus” 2008, nr 3 〈sierpień〉, s. 50-53; fragment artykułu dostępny również na stronie: http://www.similitudo.de/Zungenzauber.html 〈data dostępu: 28 VII 2015〉) - tłumacz m.in. W. Gombrowicza i współczesnej prozy polskiej, D. Masłowskiej, S. Twardocha i A. Stasiuka - rozważa ten cytat i sprawdza, jak został on oddany w niemczyźnie. W tym celu zestawia ze sobą dwa przekłady. W oryginale to szczelina jest podmiotem, a karakon zostaje zdegradowany do roli dopełnienia, co trudno wyrazić za pomocą niemieckiej składni. Daume, jak zauważa Kühl, odchodzi wyraźnie od oryginału: „Aus jeder Ritze konnte plötzlich eine Kakerlake hervorschießen" (Die Zimtläden. München 2008, s. 153) - to karakon może wystrzelić, więc jest tutaj podmiotem. Natomiast w starym tłumaczeniu H a h n a zdanie to brzmi następująco: „Jede Ritze konnte plötzlich Küchenschaben ausspeien” (Die Zimtläden. München 1961, s. 108) - według tej wersji każda szczelina mogła wypluć karakona, co jest o tyle trafne, że odpowiada intencji autora związanej z ożywieniem, upodmiotowieniem przestrzeni. 
w tekście. Podobnie jak temat metamorfozy. Schulz, wijący się na podłodze, przeistacza się w psa: warczy zamiast mówić, porusza się na czterech łapach, nie potrafi wstać. Nie jest to jednak przemiana definitywna, przypomina raczej chwilowe przeobrażenie, przybranie jakiejś formy albo pozy, zawsze niepełnej i pośredniej; od czasu do czasu pojawiają się cechy raz ludzkie, raz zwierzęce - przebiega to wyjątkowo płynnie i przypomina w swoim niedookreśleniu stan człowieka-psa z Sanatorium pod Klepsydra.

Do tego jeszcze dochodzą bohaterowie znani z prozy i dzieł plastycznych Schulza bądź też podobni do nich. Zacznijmy od postaci kobiecych: Helena, nauczycielka wychowania fizycznego i filozofii - obiekt sadomasochistycznych fantazji i pożądań Schulza - to połączenie „apostołki włochatości” Anny Csillag i dominy Magdy Wang, która „kpi sobie z męskiej stanowczości”" . Zachwyca go i budzi obrzydzenie jej niewielka, atletyczna, szczodrze owłosiona postać, podobna do małpki, z kołtunem włosów na głowie, pełnym trocin i robaków, który trąci zapachem uryny i wilgotnego, odleżanego siana $z$ klatki dla zwierząt. Inny typ kobiecości reprezentuje siostra Schulza, zajmująca się rodzinnym domem: nie tylko symbolizuje ona ciepło, matczyność, prozę życia codziennego, lecz także kryje w sobie element szaleństwa, wiary $\mathrm{w}$ to, co nierzeczywiste. Nie może ona np. pogodzić się ze śmiercią męża: w odświętnym ubraniu zawsze jest przygotowana na jego powrót, głęboko przekonana, że podróżuje on w delegacji, tak jak w opowiadaniu Karakony wszyscy mieli uznać za prawdę to, że ojciec jeździ jako komiwojażer po kraju, a nie przeistoczył się w kondora. Niezwykła postać Jakuba jest zresztą wielokrotnie bezpośrednio przywoływana w tekście, podobnie jak i matka, która nie miała nigdy zrozumienia dla jego fantazji i przygód, ale opiekowała się nim troskliwie, gdy już zupełnie zdziecinniał i żył tylko we własnym magicznym świecie. Jeszcze Adela, pies Nemrod i doktor Franck, który, tak jak Tłuja, uchodzi za miejscowego wariata: kiedyś pierwszy ateista, doznawszy religijnego objawienia, nawraca się na ortodoksyjny judaizm i niczym jeden $z$ mężów Wielkiego Zgromadzenia przemierza miasto, odprawiając modły.

Biller przywiąuje wagę do detalu. $Z$ wielka precyzją wplata w swą opowieść przedmioty niemal wyjęte $z$ Schulzowskich opowiadań. Wspomniane zostają szczotka do kurzu - własność Adeli, pudełko ze skarbami czy też dorożka. Autor bawi się nie tylko motywami, lecz także stylem drohobyckiego pisarza. Widać to po niezwykłej sugestywności i plastyczności deskrypcji. W zakreślonej fizjonomii Schulza można dopatrzyć się cytatów z jego autoportretów. Rysunki są zresztą stałym punktem odniesienia w tekście. Ciagle bowiem pojawiają się w nim krótkie ekfrazy szkiców, które już to wiszą na ścianach w piwnicznym pokoju, już to wyłaniają się z pamięci bohatera. Odwołania te uzupełniają fabułę, służą czasem jako porównania, komentarze i wizualizacje wydarzen. Występują nie tylko na płaszczyźnie fabuły: omawiane opowiadanie ukazało się w szacie graficznej zaprojektowanej z wykorzystaniem sześciu rysunków Schulza. Słowo i obraz - można by powiedzieć - splataja się tu w jedno, tak po Schulzowsku. Obrazowość tekstu Billera, gęstość zawartych w nim odniesień i aluzji do szkiców nie sprawia jednak, że akcja zastyga w bezruchu, wręcz przeciwnie: dodaje jej swoistej dynamiki. Sama czynność 
i sposób pisania listu jest niezwykle absorbująca i znajduje się ciaggle w centrum uwagi Schulza: stawiając litery wierci się on kurczowo, ześlizguje się z krzesła na podłogę, wygina się, przybiera różne pozy, zakrywa uszy, nagle coś skreśla, koryguje, potem przerywa, patrzy w lustro, zaczyna szkicować siebie, itd. Chaotyczność jego zachowania podobna jest nieco do twórczego uniesienia Józefa rysującego w Genialnej epoce, lub do wysiłków ojca, który „całym sobą” formułował list „do Chrystiana Seipla i Synów, przędzalnie i tkalnie mechaniczne"10. Opisowi gestów bohatera towarzyszy też deskrypcja samego listu - informacje na temat jego wyglądu. Malutkie szlaczki zdań w rękopisie przypominają raczej rysunek, niesprecyzowaną formę pomiędzy pismem a szkicem, albo - by posłużyć się cytatem z opowiadań Schulza - „cyrograf, na wpół tekst, na wpół obrazy, pełen kreśleń, poprawek i gryzmołów"11.

W tym miejscu warto dodać jeszcze kilka słów o języku omawianej noweli. Można bowiem odnieść wrażenie, że również na poziomie leksykalnym znajduje się w niej wiele nawiązań do prozy autora Sklepów cynamonowych. I nie są to bynajmniej poczynania epigońskie. Biller odnajduje i wypracowuje własny oryginalny styl, zdaje się jednak poruszać po obszarze podobnych do Schulzowskich skojarzeń - by tak rzec, od czasu do czasu puszcza do nich figlarnie oko. Nie sili się przy tym na naśladowanie potoczystości i barwności mowy Schulza. W omawianym opowiadaniu brak barokowych zdobień, długich i wyrafinowanych konstrukcji zdaniowych - całej tej estetyki językowego nadmiaru, która u drohobyckiego pisarza często nawet oscyluje na granicy błędu językowego, naginania reguł stylistycznych i norm gramatycznych. Biller operuje stylem bardziej minimalistycznym, jego utwór jest jednak subtelnie przetkany ciekawymi formami, nawiązującymi do prozy Schulza. Podobnie jak ten ostatni, autor Esry używa wyrazów archaicznych, przestarzałych, dziś bardzo rzadkich, takich jak, powiedzmy, „Kontorstuhl des Vaters”. Krzesło, na jakim bohater siedzi, to krzesło ojca z jego, no właśnie, „kupieckiego kantoru”, czyli biura, w którym prowadził rachunki. Natrafić też można na słowa pochodzące $z$ dialektu austriacko-galicyjskiego, jak np. znajomo brzmiący wyraz „Kanapee”, czyli kanapa (Niemcy powiedzieliby „Sofa”). Poza tym autor bawi się także egzotycznymi, wyszukanymi, często obcojęzycznymi wyrazami, zwłaszcza określającymi zwierzęta i dziwne stwory. Nie wspomina, co prawda, Schulzowskich kur belgijskich, bażantów, głuszców czy kondorów, ale mówi np. o szympansicy karłowatej bonobo („Bonobo-Dame”), o praptaku archeopteryksie („Archaeopteryxflügel”) czy też o potworze morskim krakenie („Krakenarmee”). Uwagę przykuwaja fachowe sformułowania z dziedziny architektury, które Schulz - były student tego kierunku - również wplatał w swoje opowiadania, np. u Billera w ostatniej scenie noweli bohater znajduje się przed portykiem, kolumnowym wejściem do parku miejskiego (Portikus des Stadtparks).

\section{Interpretacja}

Nadal otwarte pozostaje pytanie, co nowego wnosi nowela Billera - nowego w warstwie literackiej, artystycznej i/lub faktograficznej - poza opisana już intertekstu- 
alną zabawą dziełem Schulza? Jakie „spięcia sensów”, jakie hermeneutyczne interwencje powstają w niej i wprawiają w ruch zastaną wiedzę o drohobyckim artyście? Autor, $\mathrm{z}$ jednej strony, stara się sumiennie zrekonstruować swiat Schulzowskich opowiadań, $z$ drugiej jednak świadomie go zniekształca - proponuje zgoła odmienne estetyki i nastroje. W tekście nie ma barokowej frazy, nie ma ornamentów i arabesek, kolorowych tapet, barwnych strzępów szmatek, buzujących i kwitnaccych łopuchów - słowem: całej tej radosnej atmosfery ekstatycznej demiurgii i pulsującej materii. W Billerowskiej noweli rzeczy pozbawione sa jakby swego blasku.

Nie oznacza to jednak utraty finezji. Co prawda, Schulzowskie aluzje, napomknienia i niedopowiedzenia zastępuje tu dosadność - złośliwi dopowiedzą: iście niemiecka. Dla przykładu: dwuznaczny „,rozwiązły fluid grzechu”, unoszący się nad Ulica Krokodyli, tu jest sprowadzony do uroku domów publicznych na ulicy Stryjskiej, a zamiast tajemniczych sklepów cynamonowych mamy chaotyczne skupisko sklepików w pobliżu rynku, otwartych późnymi wieczorami na kilka godzin i oferujących gadżety erotyczne. Pewną przesadą byłoby jednak stwierdzenie, że tego rodzaju bezpośrednie sformułowania są nazbyt płaskie czy prymitywne. Subtelność tekstu Schulza zostaje tu przeniesiona na inny poziom: Biller aluzyjnie buduje mroczny klimat, oparty na przeczuciu nadchodzacej Zagłady. To moment kluczowy, który odróżnia go od autora Sanatorium pod Klepsydra i daje prawo do dowolności - kreatywności - zniekształcania i dopełniania jego prozy. W Schulzowskich opowiadaniach, zauważa Jerzy Jarzębski, wszystkie dziwactwa i fantastyczne opisy kończą się zawsze ogólną afirmacją, ponownym zapanowaniem ładu i porządku: Adela nadal miele kawę, kot myje się w słońcu - tak kończą się Sklepy cynamono$w e^{12}$. Niemiecki pisarz ma świadomość, że kontynuacja tej opowieści jest niemożliwa - raz na zawsze przerwała ją bowiem historia. Stąd i katastroficzna atmosfera, która ciąży nad analizowanym tekstem od samego początku. Stąd i ponure barwy i nastroje spowijające wszystko. Pokój bohatera to nie ptasie królestwo ojca na poddaszu, tylko ciemna piwnica, rozjaśniona nie kandelabrami czy pająkami zawieszonymi na belkach sufitu jak w opowiadaniu Traktat o manekinach. Dokończenie, lecz mała lampką dająca stłumione światło. Zamiast afirmacji i zadziwienia światem Billerowski Schulz odczuwa przede wszystkim smutek i strach. Ten ostatni to zreszta jego niezmienny towarzysz: tak jak Jakub rozmawiał z Demiurgiem, tak w noweli Bruno - ze strachem zamieszkałym w jego wnętrzu, toczącym go od środka (autor pisze właściwie o grudzie strachu, ciepłej, bezkształtnej masie ukrytej w brzuchu - trudne do przetłumaczenia określenie: „der Klumpen Angst”).

Przeczucie Zagłady wyraża się również w konstrukcji temporalnej utworu. Rozpoczyna się on konkretnym umiejscowieniem w czasie - akcja rozgrywa się w listopadowy dzień 1938 roku, skądinąd wyjątkowo ciepły, tak jak w opowiadaniu Schulza Druga jesień. Precyzyjna lokalizacja temporalna zdarzeń szybko jednak zaczyna się zacierać i dryfuje dalej w kierunku czasu bliżej nie określonego. Narrator nie sili się na „sztuczną autentyczność”: zdaje się dobrze wiedzieć o nadchodzącej wojnie, Holokauście, bliskiej śmierci Schulza, dlatego miesza ze sobą linie temporalne: artykułu dostępne na stronie: www.akcentpismo.pl/pliki/nr1.07/jarzebski.html (data dostępu: 28 VII 2015). 
perspektywa „przed” katastrofą i „po” niej nachodzą na siebie. W tekście pojawiaja się przebłyski świadomości - momenty przełamania realistycznej konwencji czasowej. Bohaterowie i narrator chwilami mówią i zachowują się tak, jakby dobrze wiedzieli, co przyniesie przyszłość. Siostra Schulza np. ma nadzieję, że po wojnie pozostanie po nich - jak powiada - nieco więcej niż trochę popiołu, no i to jeszcze, co Bruno zawarł w swoich książkach. Bruno także zdaje sobie sprawę z tego, co się wydarzy: w swoim liście pisze, iż tak czy inaczej wszyscy zginą i Bóg dla każdego przewidział odmienny koniec. Czas akcji zostaje zatem niejako zniesiony. Wydarzenia $z$ przeszłości rozgrywają się w teraźniejszości, na która pada widmo nadchodzącej katastrofy. Innymi słowy: poznając Schulza, wiemy już - tak jak on sam - że wkrótce umrze. Kompozycja opowiadania ma przenieść czytelnika w inny wymiar: podobnie jak w Sanatorium pod Klepsydra próbuje reaktywować przeszłość i zatrzymać ją, odwrócić śmierć, wbrew nieubłaganemu następstwu zdarzeń. Chronicznie nie dookreślony czas nie zyskuje przez to jednak na znaczeniu, nie nabiera jakichś dodatkowych konotacji mitycznych czy alegoryczno-symbolicznych. Po prostu staje się tylko nieco „zużyty”, pęknięty, przełamany przez świadomość historii.

Prorocze aluzje nie wyglądają na niestosowne, obce czy fałszywe wobec Schulzowskiego świata, jak może się to jeszcze wydawać w poczatkowych partiach utworu. Biller szuka/tropi zapowiedzi końca w samym dziele Schulza, snuje wyobrażenia śmierci, odwołując się do materii jego własnej imaginacji. Sięga w tym celu po niektóre z Schulzowskich motywów, powtarza je, przeakcentowuje i umieszcza w innym kontekście, dzięki czemu nabierają one nowego, złowróżbnego znaczenia. W rysunkach drohobyckiego artysty, przypominających szkice z Xięgi Batwochwalczej, narrator podkreśla widok tłumu nagich, małych, wychudzonych, słabych mężczyzn, zgromadzonych wokół podziwianej i pożądanej kobiety. Chwilę potem ten sam obraz zostaje zestawiony $\mathrm{z}$ armią umundurowanych ludzi - migawką z czasów Zagłady. W innym miejscu tekstu pojawia się z kolei znany z opowiadań Schulza motyw kolorowych iluminacji nieba, gwieździstego firmamentu, tu ukazany jako łuna pożogi wojennej. Biller stara się także odtworzyć klimat sztetla - malego miasteczka utrwalonego w Schulzowskiej prozie, ale i w tym wypadku poddaje go własnej obróbce - nieco go przekrzywia, rozkłada inaczej akcenty, „podkręca” atmosferę niesamowitości. Wszystko to czyni z przekonania, że w mikrokosmosie Schulza, pełnym dziwactw i fantazji, niewyobrażalnych i niewytłumaczalnych zjawisk, anomalii, wynaturzeń, narośli i odnóg, tkwi zarodek zbliżającej się katastrofy. Zaduch drzemiącej, ciężkiej, czarnej materii nie skłania do twórczego jej modelowania, budzi jedynie grozę. Drohobycz u Billera to siedlisko osobliwości, gdzie nic nie jest takie, jak być powinno: ludzie przemieniaja się w zwierzęta albo popadają w szaleństwo, poruszają się w jakiejś dziwacznej dorożce... W tekście stopniowo narasta napięcie, oczekiwanie na nadejście jakiegoś kolejnego kuriozum, które niechybnie w końcu dopełni obraz drohobyckich dziwactw - coś nieobliczalnego wisi w powietrzu i musi się wreszcie wydarzyć. Mieszkańcy miasta wprost wygladają pojawienia się kogoś takiego jak fałszywy Thomas Mann - i to jeszcze w roli anioła zagłady.

Co robi w mieście ów rzekomy noblista? Pretekstem do jego przyjazdu miało być poszukiwanie inspiracji do napisania nowego dzieła. Niby to ma odczyty i jakieś sprawy do załatwienia, czeka na wyrobienie wizy do Stanów Zjednoczonych, ale 
przy tym zachowuje się niczym fantom lub zjawa senna. Nomen omen, zatrzymał się w hotelu Pod Chwiejącą się Piramidą, co jeszcze potęguje skojarzenie z omamami i urojeniami. Sobowtór Manna wyczynia coraz bardziej niesamowite i nierealne rzeczy: po mieście porusza się w nocy dorożką z zaprzężonym do niej właścicielem hotelu, który, goły, parskając i wierzgając jak koń, ciągnie noblistę od jednej do drugiej knajpy. Co prawda, Billerowski Schulz podejrzewa, że to tylko zwykły oszust, pracujący na dodatek jako niemiecki agent, niemniej jednak sam daje się wciagnąć w jego gre i dopina się dobrowolnie do powozu. Punktem kulminacyjnym noweli jest scena w hotelu. Mieszkańcy Drohobycza zbieraja się w hotelowej łazience, w której rezyduje domniemany Mann. Pomieszczenie wygląda jak łaźnia w obozie koncentracyjnym - sa w nim tylko prysznice, dwie lawki i sztanga na ubrania. Goście siedzą rozebrani i słuchają w milczeniu przemówienia noblisty. Gdy dowiadują się, że być może niebawem wyjedzie, zaczynają rzucać mu się $z$ rozpaczy na szyję, proszac, by pozostał. Ten wpada w szał, wyjmuje pejcz i bije - niczym wymierzający karę siepacz/batożnik (Prügler) ${ }^{13}$ z Procesu Kafki - wszystkich naokoło jak popadnie: mężczyzn, kobiety i dzieci. W końcu, zmęczony chłostą, przyklęka nad drgająca piramidą nagich ludzkich ciał, a pomieszczenie wypełnia się metalicznoniebieskimi kłębami dymu oraz szumem natrysków.

To mocna, symboliczna scena ukazująca okrucieństwo i brutalność cywilizacji. Oto Thomas Mann, reprezentant i uosobienie kultury niemieckiej, mistrz i nauczyciel narodu - praeceptor germaniae - odpłaca się przemoca za uwielbienie oraz podziw. Sadyzm, a wraz z nim zniszczenie i zagłada, stoi u źródeł intelektualnego wyrafinowania. Fałsz i naskórkowość kulturowej otuliny, w jakiej wyrastali wielcy poeci i myśliciele, tłumaczy nieodwzajemniona miłość drohobyczan - a więc nie tylko niemieckich Żydów, jak pisze dziś Amos Elon ${ }^{14}$ - do języka, literatury i kultury niemieckiej... Biller chce być w swej krytyce bardziej uniwersalny (a może przez to też rewizjonistyczny?) - nie ma ona odnosić się tylko do Niemców. Paradoksalną relację - im bardziej uwielbiany, tym bardziej brutalny - ukazuje jako inwariant kulturowy: stosuje się on do wszystkich, zawsze i wszędzie. Na potwierdzenie tej tezy - toposu w kulturze, prawa antropologicznego - przywołuje, równolegle do akcji, starotestamentową opowieść o królu Abimeleku z Sychem. Tym samym stosuje zabieg dobrze rozpoznany w twórczości Schulza: przykładowo w opowiadaniu Wiosna historia rozgrywa się analogicznie "na wielu rozgałęzionych torach” ${ }^{15}$. Narracja Billera jest także dwutorowa: przeprowadza on paralelę między dziejami Abimeleka a losami literackiego Manna. Pierwszy z nich morduje ludzi, którzy

Proces Kafki dostępny jest w języku polskim w dwóch przekładach, a tłumaczenie słowa „Prügler” - podobnie jak wyrazu „manekin”, oddanego w prozie Schulza odmiennie przez Hahna i Daume - może pełnić funkcję jednej z obrazowych różnic między nimi. W pierwszym z nich, dokonanym w 1936 roku, sygnowanym nazwiskiem Schulza, to "siepacz” chłoszcze w rupieciarni banku strażników, którzy wcześniej aresztowali Józefa K. Natomiast w drugim, najnowszym tłumaczeniu autorstwa J. E ki e r a (Warszawa 2008) - tekście bardziej, powiedzmy, skłaniającym się ku „psychoanalitycznym interpretacjom” - Józef K. otwierając drzwi do rupieciarni, widzi „batożnika”, okładającego „pyta” skazanych strażników (s. 75-81).

14 A. Elon, Bez wzajemności: Żydzi-Niemcy 1743-1933. Przeł. K. Bratkowska, A. Geller. Warszawa 2012.

15 B. Schulz, Wiosna. W: Opowiadania. - Wybór esejów i listów, s. 145. 
obwołali go królem, i tym gestem „odwdzięcza się” im, drugi, jak powiedziano, epatuje swoich wielbicieli okrucieństwem. Nieliczni, którzy ocaleli z rzezi zgotowanej przez biblijnego króla, dopiero po masakrze nagle przypominają sobie, że ich prześladowca od dawna był morderca - wcześniej zabił przecież swoich braci. Ten zabieg narracyjny, osobliwy i surrealistyczny, nasuwa myśl, że autorowi noweli nie chodzi tylko o szokowanie. Ma ambicje bardziej poważne: pisze studium na temat unde malum, genealogii zła, stawia pesymistyczną diagnozę kultury, ostrzega przed niezmiennie czyhająca w niej przemocą, wzywa do podejrzliwości oraz piętnuje bezkrytyczną fascynację.

Bo właściwie kim niby jest ów doktor Thomas Mann? Jaki z niego sobowtór, skoro nie próbuje on nawet upodobnić się do oryginału? Cała sytuacja od samego początku sprawia wrażenie surrealistycznej i wszyscy są tego świadomi ${ }^{16}$. Przybyły do Drohobycza gość wygląda groteskowo i nie stara się tego ukryć: niechlujnie ubrany, w dziurawych butach, rozczochrany, śmierdzący, zionący nieprzyjemnym zapachem $z$ ust. Mocno upudrowany, $\mathrm{z}$ różem na policzkach oraz wąsikiem domalowanym pastą do butów - przypomina raczej klauna. Mówi niepewnie, gubi się i myli w odpowiedziach, pali niedopałki papierosów, wykłady wygłasza w aptekach, odziany w czerwony chałat. Do tego ostentacyjnie zachowuje się jak sadysta, cynik oraz antysemita, kiedy np. w poszukiwaniu materiału do nowego utworu chce przeprowadzić inscenizację pogromu Żydów. To żaden wyrafinowany hochsztapler w stylu Feliksa Krulla - tylko zwykła karykatura. Opowiadana w liście przez Schulza historia sama się neguje i de(kon)struuje, podkreśla swoją fałszywość. W ten oto sposób Biller podejmuje i rozwija jedną $z$ naczelnych zasad Schulzowskiego pojmowania rzeczywistości, najważniejszy bodaj wątek estetyki i metafizyki autora Sklepów cynamonowych. Chodzi mianowicie o „demaskację panmaskarady”, o permanentne ukazywanie, odsłanianie sztucznego i iluzorycznego charakteru świata. Dlatego w kontekście własnej twórczości Schulz mówi o „nieustannej atmosferze kulis”, wszechogarniającej aurze „panironii”, o zrzucaniu masek i kostiumów przez aktorów, o nabieraniu, o błazeńskim „wystawianiu języka” ${ }^{17}$. Podobny zabieg zostaje zastosowany w omawianej noweli. Niemal dosłownie odwzorowuje ona gest wystawienia języka - ujawnia, że jest żartem. Ciagle uderza z niej sztuczność i teatralność, która dezawuuje tekst: watpliwy Mann w całej swojej krasie, w komicznym makijażu, marzacy o barbarzyńskich inscenizacjach. Biller idzie tropem Schulzowskiej demaskacji - tylko co z tego wynika? Należy dodać, że sam Schulz zadawał sobie to pytanie i nie znajdował na nie odpowiedzi. W jednym ze swoich listów, autentycznych, do Witkacego pisał: „Jaki jest sens tej uniwersalnej dezilu-

Trudno oprzeć się pokusie poczynienia w tym miejscu uwagi, ocierającej się, być może, o czarny humor: ciekawe, czy Biller wiedział o wizycie prawdziwego Manna w Warszawie w marcu 1927, przez wielu komentowanej jako karykaturalna bądź równie surrealistyczna, jak opisywane tu historie. W swoim wykładzie Mann sprawiał wrażenie, iż nie ma pojęcia o istnieniu literatury w języku polskim, mówił za to o Tołstoju i Dostojewskim, Schillerze i Goethem, identyfikując Polskę tradycyjnie jako kraj peryferyjny pomiędzy dwoma mocarstwami: Niemcami i Rosją. Zob. sceptyczne głosy o jego wystapieniu: Tomasz Mann $w$ krytyce i literaturze polskiej. Antologia tekstów i dokumentów. Wybór, oprac. R. Dzi ergwa. Poznań 2003.

17 B. Schulz, List do St. I. Witkiewicza. W: Opowiadania. - Wybór esejów i listów, s. 477. 
zji rzeczywistości - nie potrafię powiedzieć" ${ }^{18}$. Biller mierzy się $\mathrm{z}$ tym samym problemem. Chcąc odnaleźć i zrozumieć jego rozwiązanie, trzeba najpierw rozważyć kwestię, dlaczego w tekście demaskacja łączy się z motywem sobowtóra?

\section{Powtórzyć, przekrzywić, doświadczyć}

Zestawienie dwóch wątków - deziluzji i sobowtóra - pojawia się także u Schulza w posłowiu do tłumaczenia Procesu. Stara się on tam wyjaśnić, w jaki sposób Kafka tworzy w swojej powieści świat i reguły w nim rządzace. Warto przypomnieć ów znany passus, ponieważ zawiera on również refleksję Schulza nad własnym pisarstwem, do której nawiązuje omawiana nowela. Według niego metoda Kafki:

stworzenie równoległej, s o b o w tór n ej r z e c zy wis t o ści zastępczej, [jest] właściwie bez precedensu. Ten sobowtórny charakter swej rzeczywistości osiaga on przy pomocy pewnego rodzaju pseudorealizmu, godnego osobnego studium. Kafka widzi niezwykle ostro realistyczną powierzchnię rzeczywistości, zna on niejako na pamięć jej gestykulację, całą zewnętrzną technikę zdarzeń, sytuacyj, ich zazębianie się i przeplatanie, ale jest to dla niego luźny naskórek bez korzeni, który zdejmuje jak delikatną powłokę i nakłada na swój transcendentny świat, transplantuje na swą rzeczywistość. Jego stosunek do rzeczywistości jest na wskroś ironiczny, zdradliwy, pełen złej woli - s to s unek prestidigitatora do swej aparatury. Symuluje on tylko dokładność, powagę, wysiloną precyzję tej rzeczywistości, ażeby ją tym gruntowniej skompromitow a ćl ${ }^{19}$.

Chcę tu zwrócić uwagę na dwie rzeczy. Po pierwsze, „sobowtórny charakter rzeczywistości” polega, według Schulza, na możliwie jak najdokładniejszym odtworzeniu, prawie powieleniu rzeczywistości - mowa jest o „ostrym widzeniu”, o szczególnej „dokładności”, „wysilonej precyzji” - i jednocześnie na jej przekrzywieniu, zniekształceniu. „Transplantacja naskórka” oznacza zmianę kształtu przy zachowaniu tej samej powierzchni. W takim właśnie przekrzywieniu tkwi moc wywrotowa, transgresyjny potencjał śmieszności i kompromitacji. Innymi słowy: utwór niby to udaje rzeczywistość, powtarza ją, ale $\mathrm{z}$ nieznacznym zniekształceniem, demaskującym markowane wysiłki naśladowania, „po błazeńsku” wystawiającym na pośmiewisko zarówno sam tekst, jak i przedstawiony przez niego świat. Im bardziej język (pozornie) sili się na podobieństwo do rzeczywistości, tym bardziej ją przekrzywia, kompromitując w ten sposób za jednym posunięciem ją i siebie samego. Po drugie, Schulz porównuje ów zabieg do działań prestidigitatora, który pojawia się kilkakrotnie w jego opowiadaniach. Celem iluzjonisty jest nie tylko oszustwo, nabranie publiczności, lecz powoduje nim także autoironiczna chęć rozbawienia tłumu widzów poprzez ukazanie złudzenia.

Biller podejmuje scharakteryzowaną przez Schulza „sobowtórną” taktykę deziluzji. Naśladuje świat Schulzowskiej prozy. $Z$ wielką precyzją i dokładnością przywołuje jego bohaterów, przytacza motywy, gra nimi, tak jakby poprzez tę pozorna wierność „oryginałowi” chciał legitymizować swoje pisanie. Nie zależy mu jednak na tym, by oryginał powielać, powtarza go i zarazem podważa, obala własne próby

18 Ibidem.

19 B. Schulz, Posłowie do polskiego przekładu „Procesu” Kafki. W: Opowiadania. - Wybór esejów i listów, s. 444. Podkreśl. A. H. 
symulacji. Świat ukazany w noweli - by użyć słów z Ulicy Krokodyli - „Zdradza swą imitatywność" ${ }^{20}$, nie stara się ukryć fikcyjności i karykaturalnosci, podkreśla własną fantastyczność i absurdalność. Jest to zatem świat „sobowtórny” w stosunku do rzeczywistości Schulza, tak samo „sobowtórny” jak ten nieszczęsny oszust podający się za Manna wobec rzeczywistego autora Buddenbroków. Oszust, który poprzez swoją karykaturalność i świadomość historyczną czytelnika - sam się ujawnia i kompromituje. Wciąż otwarte pozostaje pytanie, jaką wartość, jaki cel i sens ma to demaskatorskie przekrzywienie?

Najlepiej będzie znów najpierw oddać głos Schulzowi, który w opowiadaniu Wiosna tak oto rozwija watek prestidigitatora i deziluzji:

Widziałem raz prestidigitatora. Stał on na estradzie szczupły, ze wszech stron widoczny, i demonstrował swój cylinder, ukazując wszystkim puste jego i białe dno. W ten sposób zabezpieczywszy swą sztukę ponad wszelka wątpliwość przed podejrzeniem oszukańczych manipulacji, zakreślił pałeczką w powietrzu splątany swój znak magiczny i natychmiast zaczął z przesadną precyzją i nao c z n o ś cią wywlekać laseczką z cylindra wstążki papierowe, kolorowe wstążki, łokciami, sążniami, na koniec kilometrami. Pokój napełniał się tą kolorową szeleszczącą masa, stawał się jasny od tego stokrotnego rozmnożenia, od spienionej i lekkiej bibułki, od świetlanego spiętrzenia, a on nie przestawał wywlekać tego nie kończącego się wątka, mimo przerażonych głosów, pełnych zachwyconego protestu, okrzyków ekstazy, spazmatycznych płaczów, ażw końcu stawało się jasne, jak na dłoni, że go to nic nie kosztuje, że czerpie tę obfitość nie z własnych zasobów, że mu po prostu otworzyły się źródła nadziemskie, nie podług ludzkich miar i rachub.

Ktoś wówczas, predestynowany do recepcji głębs ze go sensu tej demonstracji, odchodził do domu zamyślony i olśniony wewnętrznie, przeniknięty do głębi prawdą, która weń weszła: Bóg je st nieprzeliczony... ${ }^{21}$

We fragmencie tym mamy do czynienia $z$ kontaminacja wszystkich dotychczasowych wątków. Sytuacja jest teatralna - iluzjonista stoi na scenie przed publicznością. Swoje sztuczki prezentuje ze zbytnią dokładnością, przesadnie stara się, by wyglądały na wiarygodne. Wszyscy od początku jednak wiedzą, że to prestidigitator, zwykły sztukmistrz, który ich nabiera, a nie cudotwórca czy mesjasz - nie oczekuja od niego objawienia prawdy. Jego triki pasuja w zasadzie idealnie do estetyki karnawałowej Schulza, ale są nieproporcjonalne do powagi, z jaka prezentuje je magik. Mimo raczej ubogiego repertuaru wywołuje on u widzów ekstremalne uczucia: ekstaze, płacz, przerażenie, protest, zachwyt. Co więcej, dla niektórych to doświadczenie stanowi nawet źródło mistycznego przeżycia. Jak to możliwe? Widz daje się wciaggnąc w czar iluzji, mając przy tym świadomość, że to oszustwo; doznaje „odchylenia” od normy, demaskuje rzeczywistość, która jest mu niby dobrze znana, choć ciagle nie do końca poznawalna, przewidywalna, obliczalna; doświadcza jej „sobowtórnej” wersji, czyli takiej, która naśladuje rzeczywistość, posługuje się i legitymizuje się jej logiką (np. demonstracja dna cylindra), z precyzją unaocznia jej zasady, jednocześnie wykrzywiając i naginając je do swoich fabularnych celów. Paradoks polega na tym, że tylko takie doświadczenie dociera do najbardziej podstawowych, źródłowych warstw rzeczywistości - i tylko ono jest w stanie wywołać silne emocje, ocierające się nawet o unio mystica.

Można odnieść wrażenie, iż Biller przyjmuje w swym tekście podobny zamiar.

20 B. Schulz, Ulica Krokodyli. W: jw., s. 80.

21 Schulz, Wiosna, s. 158-159. Podkreśl. A. H. 
Jak już wspomniałam, najpierw naśladuje on rzeczywistość z Schulzowskiej prozy, by następnie stopniowo ją zniekształcać i jednocześnie demaskować to zniekształcenie - ale co chce on poprzez to osiagnąć? Otóż treść noweli $W$ gtowie Brunona Schulza, tak samo jak prestidigitator w opowiadaniu Wiosna, również pośredniczy w przeżyciu czegoś pierwotnego, niewyobrażalnego i nieosiagalnego. Nie ma to być jednak transcendencja, Boski absolut, bardziej prawdopodobne jest raczej coś z poziomu profanum - przeszłość, wszystko to, co bezpowrotnie przeminęło. Utwór dotyka bowiem problemu pamięci i mierzy się z pytaniami: jak ocalić jednostkowy los od zapomnienia? Jak utrwalić indiwiduum, jak o nim opowiadać, żeby nie uprzedmiotowić go, nie wpleść w wielkie narracje o wydarzeniach historycznych i nie zatrzeć przez to jego własnego doświadczenia, nie rozpuścić go w uniwersalnych prawach i prawdach? Jak świadczyć - to nie to samo co „poznawać”! - o przeszłości i czynić ją dotykalną, przenieść do teraźniejszości?

Te dylematy są explicite sformułowane w tekście. W trakcie brutalnej sceny w łaźni rzekomy Thomas Mann, wybiczowawszy bestialsko otaczających go ludzi, odsyła Schulza do domu i każe mu pracować tam nad nową powieścią Mesjasz. Przepowiada mu przy tym, że gdy tylko pisarz ją ukończy, do Drohobycza przybędą bandyci, którzy spalą całe miasto wraz z nim i jego manuskryptem. Na koniec Mann dodaje jeszcze, iż ta historia byłaby świetnym materiałem na dzieło literackie, tylko kto miałby je napisać, kiedy Schulz już umrze? Inaczej mówiąc: kto i jak ocali go od zapomnienia?

Sądzę, że ukazana przed chwila „sobowtórność”, to sedno rozumienia pamięci $\mathrm{w}$ analizowanym tu utworze: jej istotę stanowi powtarzanie i przekrzywianie. Powtarzenie jako podstawa rytuału od zawsze było formą utrwalania, zwłaszcza w kulturach przedpiśmiennych. Znosząc czas, łączyło przeszłość z przyszłością, nadawało cykliczny rytm. Tekst stara się odtworzyć przeszłość, rekonstruuje wydarzenia z dbałością o szczegóły, ale też zniekształca, przekrzywia, przesuwa - i nie ukrywa tego, wręcz sam się demaskuje. Jakie znaczenie należy przypisać tej deformacji? Czy trzeba w niej upatrywać nieuchronnej klęski pamięci, która nigdy nie będzie w stanie odtworzyć minionych wydarzeń? Biller ciagle podkreśla brak identyczności pamięci z przeszłością - przesunięcie między nimi to nie rezultat porażki artystycznej, lecz raczej wyraz „zbawiennej” mocy czy wręcz mesjanistycznego potencjału sztuki. Sprawia ono bowiem, że praca pamięci ma charakter kreacyjny, procesualny, nigdy nie jest dana i definitywnie zamknięta, dąży do uchwycenia minionego, które ciagle jej się wymyka, stąd naprzemienne powtarzanie oraz zniekształcanie go. Tak samo, ale trochę inaczej - tymi słowy można by streścić zasadę pamięci. To „trochę inaczej” wydaje się tu istotne, ponieważ podkreśla jej aktualny wymiar: przekrzywienie przypisane jest do czasu teraźniejszego, tak jak datowanie za każdym razem w odmienny sposób naznacza - czytaj: zniekształca - powtórzenie. Odtwarzana przeszłość nigdy nie okazuje się taka sama. Dzięki gestowi nieznacznego przekrzywienia za każdym razem musi być trochę inaczej doświadczana tu i teraz. Takie rozumienie pamięci nie rozpatruje czasu minionego chronologicznie w postaci liniowego następstwa zdarzeń, uchwytnej jedności. Pamięć jawi się jako niekończący się proces rozszczepiania i przekrzywiania, stale otwarty na nowe, alternatywne przebiegi. Rzec by można, że nie działa ona rewolucyjnie - w swojej powtarzalności, iteratywności zadowala się drobnymi przekształceniami tego, co minęło. 
Na koniec tych rozważań jeszcze dygresja: niewielkie przekrzywienie/przesunięcie („kleine Verrückung”) jako możliwość i źródło restytucji przeszłości to znany topos w niektórych judaistycznych wizjach mesjanizmu. Zakładają one, że nadejście Mesjasza nie wprowadzi zmian radykalnych, tylko nieznaczne - wszystko zostanie tak jakby trochę przesunięte, a poza tym będzie takie samo, jakim było przed Jego przybyciem. To wyobrażenie, czasami określane jako „mesjański minimalizm” (np. przez Hansa Blumenberga ${ }^{22}$ ), w poprzednim stuleciu silnie eksploatowała filozofia, pojawia się ono m.in. w pismach Ernsta Blocha i Waltera Benjamina. Ten ostatni w swoim tekście poświęconym Kafce przywołuje chasydzkie przysłowie „pewnego wielkiego rabina”, który o Mesjaszu miał powiedzieć, „że nie chce wcale zmieniać swiata przemoca, a jedynie go trochę poprawi" 23 . Benjamin przytacza te słowa w kontekście rozważań nad „zniekształconym” (,entstellt”) życiem - jego przykładami mają być Kafkowski Odradek czy Garbusek, postać z ludowej piosenki. Ich status pozostaje nieokreślony, nie daje się skategoryzować, to twory zdeformowane, liche, marne i zapomniane (Odradek przerzucany jest ze strychu na korytarz, nie do końca wiadomo, co z nim zrobić, stąd i troska ojca rodziny), które domagają się zwrócenia na nie uwagi (Garbusek prosi w wierszyku, by zmówić za niego paciorek). Benjamin wierzy, że zniekształcone życie może zostać uratowane i zniknie, gdy przyjdzie Mesjasz i dokona owego niewielkiego przesunięcia. Wówczas to, co ułomne i niedoskonałe będzie miało szansę na zbawienie. Da się to ująć też inaczej: „wtedy krzywe stanie się prostym”, zgodnie z frazą biblijną, tą samą, z której skorzystał Agnon w tytule swojego opowiadania, a która Biller uczynił mottem noweli. Zbawienny gest niewielkiego przesunięcia nie przynależy jednak tylko Bogu, jest także dziełem ludzkim, zawarty w pracy pamięci, określanej przez Benjamina w innych jego dziełach jako „Eingedenken”. Pojęcie to - trudno przekładalne na język polski przy użyciu jednego słowa, opisowo wyjaśniane jako „ruch pomnienia czy upomnienia się”, od zwrotu „eingedenk sein”, czyli 'być pomnym czegoś, co bezpowrotnie utracone'24 - oznacza szczególny gest pamięci, ten sam, który, jak sądzę, udało się przedstawić literacko Billerowi. Ukazany w noweli minimalizm pamięci jawi się w tym kontekście niemal jako replika minimalizmu mesjańskiego, który właściwie dałoby się uznać za filozoficzno-literacką wariację na temat stworzenia człowieka na obraz i podobieństwo Boże: działamy, lub raczej nasza pamięć działa, tak samo jak Mesjasz.

O „Eingedenken” Benjamin pisze m.in. w swoim tekście O pojęciu historii. „Pomnienie" to według niego rodzaj pamięci empirycznej, bliskiej doświadczeniu. Zwraca on np. uwagę na to, że Tora i modlitwa „ćwiczą w pomnieniu”, pomagają $\mathrm{w}$ uobecnianiu minionego, nie istniejącego w czasie danym jako teraz, w które (minione) zawsze wkroczyć może owo „nieobecne”, zdolne powstrzymać bieg wydarzeń i tym samym wyzwolić „uciśnioną przeszłość”. Ma ono zatem charakter pro-

H. Blum e n berg, Matthäuspassion. Frankfurt am Main 1988, s. 273-277.

W. B e nj a m i n, Franz Kafka. Z okazji dziesiatej rocznicy jego śmierci. Przeł. A. Li p s zy c. W zb.: Nienasycenie. Filozofowie o Kafce. Red. Ł. Musiał, A. Ży chlińs ki. Kraków 2011, s. 50-51. M. Ole s i k, Lipszyc: Celan-język i Zagłada. Rozmowa z A. Lipszycem. „Dziennik Opinii. Krytyka Polityczna” 2013, nr z 18 XI. Dostępne na stronie: http://www.krytykapolityczna.pl/artykuly/ kultura/20131117/lipszyc-celan-jezyk-i-zaglada (data dostępu: 24 VII 2015). 
cesualny i otwarty, znosi linearność historii, zwraca się ku przyszłości i nie przesądza znaczeń minionych wydarzeń, zostawia dla nich otwartą „małą furtkę”, przez która „w każdej sekundzie może wkroczyć Mesjasz”25. Albo - każdy z nas, bo przecież także i o to tu chodzi. Podmiotami tego rodzaju pamięci są ci, dla których zwykle nie ma miejsca na kartach historii - zwyciężeni, zapomniani, uciskani. „Eingedenken” wydaje się w tym pokrewne sztuce, ponieważ jedną z jej funkcji zawsze było przecież wydobywanie z zapomnienia, udzielanie głosu temu, co wyparte, słabe i stłumione. Pamięć staje się tu sposobem ludzkiego istnienia, radzenia sobie $z$ przygodnością, przemykania/przezierania przez szczelinę teraźniejszości. Tak zrozumiana, znajduje swoją literacką realizację w utworze Billera. I tylko ona może też wytłumaczyć finał noweli:

Schulz biegnie przez miasto nago, na czworakach, jako pół człowiek, pół pies, z kopertą listu do Thomasa Manna w zębach. Wokół pożoga wojenna, czołgi i pożar, ptaki wlatują w ogień i płoną. On jednak, choć okaleczony i krwawiący, ucieka dalej. Nie spotka go los Kafkowskiego Józefa K., który zostaje zamordowany - a tak brzmi ostatnie zdanie Procesu - ,jak pies”. Właściwie bagatelizuje cała sytuację, cieszy się na spotkanie z kobietą, na samą myśl o sadomasochistycznych przyjemnościach... Przemyka koło drohobyckiego parku, tam gdzie w rzeczywistości znajduje się tablica upamiętniająca jego śmierć. Ale on nie umiera, zatrzymuje się przy portyku, przy parkowej furcie - być może, otwartej...

\author{
Abstract \\ AGNIESZKA HUDZIK Freie Universität Berlin
}

EXPERIENCE AND MEMORY WITH AN OPEN GATE MAXIM BILLER ABOUT BRUNO SCHULZ

The article touches Maxim Biller's novel published in 2013 Im Kopf von Bruno Schulz which was translated into Polish by Małgorzata Mirońska (Warsaw 2014) under the title W głowie Brunona Schulza (In Bruno Schulz's Head). The text is composed of four parts. In the first one Hudzik briefly presents the author whose creativity has not to date been translated into Polish. She also focuses on the book's content and tries to set it in the context of other literary fictions the protagonist of which is Schulz and/or his manuscripts. Starting point of the novel is a legendary letter that Schulz was supposed to send before the World War II to Thomas Mann with his only short story written in German. Hudzik asks for reasonableness and aptness of confabulation of historical material in the literary work which is not biographical in its nature. In the second part Hudzik analyses the content of the novel: allusions and intertextual references to Schulz's works, especially the motifs of a double and unmasking. The third part is to give answer to the question what new matters Biller's novel offers - the new in the literary, artistic and/or fact-collecting sphere, apart from an intertextual play with Schulz's work. The last part of the article is devoted to the problem of memory. To understand the work of memory described in the book, Hudzik refers, inter alia, to Walter Benjamin's concept of "kleine Verrückung [slight twisting/shifting]" and "Eingedenken [Remembrance]". kowicz. Wstęp A. Lip s zy c. Kraków 2012, s. 323. 